gency. While in any particular case, appreciation after resale may be small, the possibility of large appreciation damages may deter a trustee contemplating. appropriation of trust property, especially if his expectation was that the property would later appreciate to permit profits on resale. Moreover, the trustee's bad faith in the initial transfer suggests the possibility of a collusive transfer between the trustee and the purported bona fide purchaser. ${ }^{32}$ However, it may be pointed out that there already exist sanctions peculiarly applicable to the trustee who has acted in bad faith. For example, in his accounting certain credits are disallowed, ${ }^{33}$ and in proper cases criminal sanctions exist. ${ }^{34}$ Thus the question of imposing appreciation damages on a trustee who has acted in bad faith is a close one. However, it is clear that, in the absence of bad faith, appreciation damages would be an unduly severe measure, unnecessary for adequate protection of beneficiaries.

tration 159-61 (1940). If the trustee is acting in bad faith he may be more likely to conceal his purchase and thereby make discovery and accountability less likely, with the result that more stringent penalties are needed to achieve adequate deterrence. See 3 Bogert, op. cit. supra note 2, at 100 n.55, quoting from Conway v. Green's Adm'r, 1 Har. \& J. (Md.) 151, 152 (1801).

${ }^{32}$ Assume a case where the trustee, having appropriated the property, now senses that the beneficiary will soon discover the breach and compel reconveyance. If the trustee believes the property will appreciate, a bogus transfer accepted by the court at face value would defeat the action for reconveyance, thereby permitting the trustee to take advantage of the appreciation. Where there is no evidence that the trustee has acted in bad faith, there is less reason to infer a collusive transfer. A clear showing of bona fide transfer would defeat the inference in either case.

${ }^{33}$ See notes 29 and 30 supra.

34 2 Bishop, Criminal Law c.16 (9th ed., 1923).

Even if a rule surcharging bad faith trustees for appreciation damages is rejected, the measure of relief should be based not on the resale price, but on the market value on the date of resale, because bad faith trustees may be willing to sell at a low price in an endeavor to avoid discovery or to obtain cash for further speculation. This is apparently the rule in Pennsylvania. Powers v. Black, $159 \mathrm{~Pa} .153,28 \mathrm{Atl} .133$ (1893). Where the trustee has acted in good faith throughout, there seems to be a presumption that he received a fair price on resale. Id., at 157, 134. But cf. Ricketts and Whittington v. Montgomery, $15 \mathrm{Md} .46$ (1860).

The Pennsylvania rule solves the troublesome problem of a trustee who sold to himself at a time when sale was proper but who sold to a bona fide purchaser at a time when the market was such that the property should have been retained. The situation is extremely hypothetical, particularly in view of courts' hesitancy to find a duty to retain solely on market or expected market. See In re Guaranty Trust Co. of New York, 188 Misc. 61,69 N.Y.S.2d 416 (Surr. Ct., 1945); Rest. Trusts $\$ 208$, Comment b (1935). Nevertheless, absent this presumption, appreciation damages would be a proper remedy.

\title{
THE POWER OF AN ADMINISTRATIVE AGENCY TO ATTACH TERMS AND CONDITIONS TO OFFICIAL ACTION
}

Administrative agencies have frequently achieved extensive regulation of matters apparently beyond their statutory authority by attaching terms and conditions to official action. For example, the Civil Aeronautics Board for 
many years has maintained the system of non-scheduled airlines by requiring, as a condition to registration of these airlines, that their schedules be irregular. ${ }^{1}$ Yet no express statutory authority exists for attaching conditions to these registrations, ${ }^{2}$ and there is some indication that the Civil Aeronautics Act prohibits the CAB from regulation of schedules. ${ }^{3}$ Both the Interstate Commerce Commission and the $\mathrm{CAB}$ have required, as a condition to approval of mergers, that the carriers make payments to employees laid off as a result of the merger and that relative seniority rights of employees of the merging carriers be adjusted in a prescribed fashion. ${ }^{4}$ Yet it seems doubtful that these agencies were established to supervise labor relations. Numerous similar examples raise the general questions of when the power to attach terms and conditions exists and what limitations can be imposed on its exercise. ${ }^{5}$

Conditions have been held valid where no express statutory authority to attach them existed, ${ }^{6}$ and this holding seems correct wherever the conditions could have been imposed either by a direct rule or by an agency announcement that, as a rule of decision, action would not be taken at the instance of applicants not fulfilling the conditions. ${ }^{7}$ Where a condition could be imposed by such

${ }^{1}$ See Air Transport Associates v. CAB, 199 F.2d 181 (App. D.C., 1952).

2 Non-scheduled airlines are registered under Section 416 of the Civil Aeronautics Act. 52 Stat. 1004 (1938), 49 U.S.C.A. $\$ 496$ (b)(1) (1951).

s 52 Stat. 987 (1938), 49 U.S.C.A. $\$ 481(\mathrm{f})$ (1951).

4 United States v. Lowden, 308 U.S. 225 (1939); Kent v. CAB, 204 F.2d 263 (C.A.2d, 1953); Western Airlines, Inc. v. CAB, 194 F.2d 211 (C.A.9th, 1952); Braniff Mid-Continent Merger Case, 15 C.A.B. 708 (1952). United States v. Lowden, which sustained the ICC's power to attach such conditions, was confirmed by statute. 54 Stat. 905 (1940), 49 U.S.C.A. $\S 5(2)(f)$ (Supp., 1956).

${ }^{5}$ See United Airlines, Inc.-Western Air Lines, Inc., Acquisition of Air Carrier Property, 8 C.A.B. 298 (1947), and cases cited therein at 346-47; Administration by the Federal Power Commission of the Certificate Provisions of the Natural Gas Act, 14 Geo. Wash. L. Rev. 194, 213-15 (1945). For a general discussion, see Freund, Administrative Powers over Persons and Property 113-17 (1928).

When a court decides to strike down conditions attached to an agency order, a further problem arises as to whether the order should be affirmed as modified or remanded for reconsideration by the agency. On this question the cases are in conflict. E.g., United States v. Chicago, Milwaukee, St. Paul \& Pac. R.R. Co., 282 U.S. 311 (1931) (order affirmed as modified); People ex rel. Iroquois Gas Corp. v. Public Service Commission, 264 N.Y. 17, 189 N.E.764 (1934) (order remanded for reconsideration). A remand for reconsideration appears to be the better course. If the reviewing court is to be consistent, the agency could not on remand refuse the order because the applicant did not fulfill the conditions which the agency had unsuccessfully sought to attach. See text at 396-98 infra. However, it would seem that the agency should be given an opportunity to consider whether the order might be refused on other grounds. Cf. SEC v. Chenery Corp., 318 U.S. 80 (1943), 332 U.S. 194 (1947).

6 Yellow Cab Co. v. Public Utility Hearing Board, 73 R.I. 217, 54 A.2d 28 (1947). Cf. the municipal corporation cases discussed in note 10 infra.

7 For an example of "rule-making" through such an announcement, see Columbia Broadcasting System, Inc. v. United States, 316 U.S. 407 (1942). $\because \therefore$ 
"rule-making," it would seem futile to deny the agency power to attach this condition to its action, ${ }^{8}$ and no court has done so. ${ }^{9}$

The further question arises as to whether the power to attach conditions is limited by the scope of the rule-making authority. Where no express statutory authorization exists for attaching conditions, such a limitation should be imposed. The reason for inferring a power to attach conditions is that the agency can make rules which have the effect of attaching conditions; this reason does not apply to conditions which could not have been required by rule. ${ }^{10}$

${ }^{8}$ It has been argued that there are some matters which should not be the subject of conditions even though they may be the subject of agency rules for when action will be taken. In Petition of Derry Electric Co., 180 Atl. 697 (N.H., 1935), the court, answering two questions certified from a proceeding for approval of a utility security issue, held that the commission could consider the types of securities proposed in deciding whether to approve the issue, but that the commission could not, as a condition of approval, specify the types of security to be issued. "[T]he commission may not directly impose upon the utility a financial scheme devised by the commission and not requested by the company. It may well be that the utility, after trying vainly several proposals, will hit upon one that the commission can approve, but it is not for the commission independently to plan the financial structure of the utility and then order the owners and managers to accept it." Id., at 704. This argument, however, is futile, if the commission could have imposed its own financial scheme, without attaching conditions, by making a rule requiring denial of applications not providing for this particular scheme. On the other hand, if the commission could not have made such a rule-if it would have had to approve applications providing for any one of a number of financial plans-then the court's denial of the power to attach a condition requiring a particular plan from this number does not impair the principle that an agency can attach any condition which it can require by rule. Cf. Petition of New Hampshire Gas \& Electric Co., 88 N.H. 50, 184 Atl. 602 (1936).

- Many cases strike down conditions where statutory authorization for attaching conditions is lacking. But in these cases the reasoning indicates that conditions which could have been directly imposed by rule will be upheld. Chicago District Pipeline Co. v. Illinois Commerce Commission, 361 IIl. 296, 197 N.E. 873 (1935); People ex rel. Iroquois Gas Corp. v. Public Service Commission, 264 N.Y. 17, 189 N.E. 764 (1934); People ex rel. New York Central \& H.R.R. Co., 227 N.Y. 248, 125 N.E. 438 (1919); cf. Dep't of Public Utilities v. R. O. McConnell, 198 Ark. 502, 130 S.W.2d 9 (1939). Thus in the Iroquois case, while the court said that the Commission, without express statutory authority to attach conditions, might give "a denial of consent to the transfer as proposed, coupled with unconditional approval of a different transfer," the condition before the court was struck down because "it requires the purchaser to make an entry upon its books which the commission would have no power to direct." People ex rel. Iroquois Gas Corp. v. Public Service Commission, supra, at 19, 765.

${ }^{10}$ Many state cases grant municipalities power to attach to utility franchises conditions which could not be ordered directly. E.g., Athens Telephone Co. v. City of Athens, 182 S.W. 42 (Tex. Civ. App., 1915); cf. City of Jamestown v. Pennsylvania Gas Co., 1 F.2d 871 (C.A. $2 d, 1924)$. A common holding is that, while a city may not tax a utility, it may require, as a condition of the franchise, that the utility pay the city each year a given percentage of gross receipts or a lump sum. Nashville Gas and Heating Co. v. City of Nashville, 177 Tenn. 590, 152 S.W.2d 229 (1941); City of Baker v. Montana Petroleum Co., 99 Mont. 465, 44 P.2d 735 (1935); City of Hartford v. Connecticut Co., 107 Conn. 312, 140 Atl. 734 (1928); City of Oshkosh v. Eastern Wisconsin Electric Co., 172 Wis. 85, 178 N.W. 308 (1920); Appeal of Carlisle \& MI.S. Ry. Co., 245 Pa. 561, 91 Atl. 959 (1914). Contra: Village of Lombard v. Illinois Bell Telephone Co., $405 \mathrm{Ill}$. 209, 90 N.E.2d 105 (1950). The situation appears analogous to that of an administrative agency. Just as certain businesses cannot operate without an agency-granted certificate, utilities cannot operate within city limits without a franchise. And a city, as well as any agency, can only exercise those powers delegated to it by statute. The municipal corpora- 
Where express statutory authorization for attaching conditions exists, a similar result should be reached." If powers to make rules and to attach conditions can be used interchangeably, a limitation, to be effective, must be read as a limitation on both powers, even though it is applicable in terms to one alone. While this reasoning results in partially restricting the general scope of one power, the alternative of wholly nullifying an express statutory limitation on the other seems to be a less plausible kind of interpretation. ${ }^{12}$

The meaning of express statutory limitations on agency power to attach conditions or make rules is not suitable for general discussion, since it involves interpretation of the particular statute with reference to the peculiar circumstances of the agency involved. However, it would seem that the power to attach conditions should be subject to certain implied limitations which are generally applicable.

It might be thought that a power to attach conditions should not be used to achieve results which are specifically prohibited by statute, or results for the achievement of which the statute establishes some other procedure. But the Supreme Court has held that these two limitations do not apply. In Allantic Coast Line R. Co. v. United States, ${ }^{13}$ the ICC, using its statutory power to attach "just and reasonable" terms and conditions to approval of a lease, required a railroad to consent to be "short-hauled" on a through route running over the leased tracks, despite the fact that another section of the Act set up a procedure for establishment of through routes and provided that "[i]n establishing any such through route the commission shall not . . . require any carrier

tion cases, however, present a significant doctrinal distinction. The cases cited above upholding franchise conditions speak of the franchise as a "contract" for the use of city streets; franchise taxes are not taxes, but "rentals" for the use of city property. Thus the Supreme Court, in Georgia Power Co. v. Decatur, 281 U.S. 505 (1930), refused to consider the question of whether a five-cent streetcar fare, imposed by franchise, was confiscatory, on the ground that a contract provision cannot confiscate. This argument will not be applied to conditions attached to agency action. United States v. Chicago, Milwaukee, St. Paul \& Pac. R. Co., 282 U.S. 311 (1931) (conditions attached by ICC to approval of a reorganization plan struck down as violative of Due Process and Commerce Clauses).

11 See note 9 supra. In United States v. Lowden, 308 U.S. 225 (1939), the Court assumed arguendo that conditions attached by the ICC to approval of a railroad lease had to meet not only the express statutory requirement that they be "just and reasonable," but also the requirement of "public interest" imposed by the statute as the standard the Commission must follow in deciding whether to approve a railroad lease. Since prior cases had interpreted this "public interest" standard to mean "public interest in an adequate and efficient transportation system," the Court, in upholding the Commission, had to argue that the conditions attached affected railroad service to the public - an argument which was difficult to make, since the conditions merely required that certain employees of a railroad accounting office be compensated for unemployment resulting from the lease.

${ }^{12}$ This conclusion is open to the objection that, due to its similarity with the conclusion reached for cases in which no statutory authorization for attaching conditions exists, it renders such statutory authorization superfiuous.

13 284 U.S. 288 (1932). 
by railroad, without its consent," to be short-hauled. ${ }^{14}$ The district court, upholding the ICC, relied on the railroad's consent to the condition..$^{15}$ While this consent seems largely fictitious, it may present a ground of distinction from cases involving conditions attached to operating certificates, the loss of which would be so disastrous to a business that a "consent" imposed as an alternative would be wholly fictitious. The Supreme Court relied on a different argument to uphold the Commission. To justify evasion of the prohibition of the short haul, the Court argued that it applies only to routes established pursuant to the procedure set up by the preceding subsection; by avoiding use of the statutory procedure for exercise of the power to establish through routes, the ICC managed to avoid the statutory restrictions on that power. To justify evasion of the statutory procedure, the Court argued that the prohibition of the short haul was intended to protect only existing routes; the Atlantic Coast Line was to be short-hauled only over the tracks which the Commission's order authorized the Line to lease. ${ }^{16}$ While the Court cited nothing in the statute or legislative history to support this limitation of the short-haul prohibition, the interpretation has some plausibility and might present a ground of distinction from cases in which the statutory prohibition was intended to do more than protect only existing rights.

In a more recent case, presenting none of the distinguishing features of Atlantic Coast Line, the Court upheld conditions which evaded a statutory prohibition. In United States v. Rock Island Co., ${ }^{17}$ the ICC, having attached to a motor carrier's operating certificate the condition that further conditions could be later attached, now proposed to attach such further conditions. The original condition seemed to violate Section 212(a) of the Interstate Commerce Act, which, according to the Court, allows "change or revocation" of certificates only for the holder's willful violation of the Act or of orders thereunder; $;^{18}$ no such

14 "In establishing any such through route the commission shall not . . . require any carrier by railroad, without its consent, to embrace in such route substantially less than the entire length of its railroad and of any intermediate railroad operated in conjunction and under a common management or control therewith, which lies between the termini of such proposed through route. . . " 24 Stat. 384 (1887), as amended, 49 U.S.C.A. $\$ 15$ (4) (1926).

${ }^{15}$ Atlantic Coast Line R. Co. v. United States, 48 F.2d 239 (W.D. S.C., 1931). Compare Central West Utility Co. v. Federal Power Commission, 247 F.2d 306, 311 (C.A. 3d, 1957).

16 "The limitation imposed by $\$ 15(4)$ of the Act upon the Commission's power under $\$ 15(3)$ to establish through routes is designed to protect the existing long-haul routes of carriers. ... It applies only when the Commission is exercising the power conferred by that paragraph. It is not a limitation upon the power of the Commission to approve new combinations of carriers." Atlantic Coast Line R. Co. v. United States, 284 U.S. 288, 295 (1932). This language indicates that, by "existing routes," the Court means routes existing under a valid operating certificate at the time the Commission chooses to establish a through route. Under this argument, an applicant for a certificate might have no "existing rights" in regard to the operations for which the certificate is sought and so might find that the agency can attach to the certificate any conditions not violating statutory limitations expressly applicable to the power to attach conditions.

17340 U.S. 419 (1951). $\quad{ }^{18}$ Id., at 435. 
violation had been shown on the part of Rock Island. Despite the fact that "consent" could hardly have been found, since rejection of the condition would have involved loss of an operating certificate, and that Section 212(a) could not have been intended only to protect a carrier's rights existing at the time it applies for a certificate, ${ }^{19}$ the Court upheld the ICC's imposition of further conditions. The Court argued that the original condition only allowed further conditions which would be consistent with the policy of the Act; a condition giving the Commission unfettered power to change the certificate would, according to the Court, violate Section 212(a). Since consistency with the policy of the Act would seem to be a requirement for any Commission action, the Court in effect held that Section 212(a) in no circumstances constitutes a limitation on Commission power to attach conditions. ${ }^{20}$ Under this holding it is difficult to see how any conditions, which do not contravene statutory limitations expressly

19 See note 16 supra.

${ }^{20}$ There are two grounds on which this broad holding might be distinguished. In the first place, the original condition reserved the right to impose only such further conditions as would insure that Rock Island's motor carrier service would remain "supplemental" to the parent company's train service. Since the original certificate was limited to such "supplemental" service, it might be argued that the further conditions were simply an administrative definition of the terms of the original certificate. United States v. Rock Island Co., 340 U.S. $419,435,443$ (1951). Nevertheless, the further conditions probably did "change" the certificate in the sense of requiring a specific kind of supplemental service where other types of service might also have fallen within the term "supplemental"; the further conditions seem to have changed formerly authorized acts into violations of the certificate. The Court's reference to these conditions as "further limitations, restrictions or modifications" tends to support this interpretation. Id., at 435 .

The Rock Island case can also be distinguished on the ground that another ground of decision was available. To support the result, the Court in one sentence "notes" Section 208 of the Act, providing that "there shall, at the time of issuance and from time to time thereafter, be attached to the exercise of the privileges granted by the certificate such reasonable terms, conditions and limitations as the public convenience and necessity may from time to time require." 49 Stat. 552 (1935), 49 U.S.C.A. $\$ 308$ (1951) (emphasis supplied); quoted in United States v. Rock Island Co., supra, at 435-36. Not only could this section have provided the sole basis for the result, it also indicates that the ICC could have imposed further conditions without a reserved power to do so in the original certificate. The Court's interpretation of Section 212(a) as prohibiting "change" of the certificate without a showing of the holder's willful violation seems to contradict Section 208 and is not required by Section 212(a), which permits "change or revocation" on a showing of the holder's willful violation of the Act or orders thereunder, but which requires such a showing only for "revocation." (The showing required for "revocation" is limited to violations of Commission orders issued pursuant to a proceeding at which past violations of the Act have been shown.) 49 Stat. 555 (1935), as amended, 49 U.S.C.A. $\$ 312$ (a) (1951). The dissenting justices seem to have realized this argument; in stating that the Commission's action was unauthorized by the Act, they avoid the word "change" by saying that the Commission "partially revoked" the certificate. United States v. Rock Island Co., supra, at 449.

It might also be noted that any further conditions imposed pursuant to the original condition could only obtain while the motor carrier service was owned by Rock Island Railroad Company; in the hands of an independent buyer there would be no necessity that the service remain "supplemental" to Rock Island's train service. Thus the condition did not impair Rock Island's ability to recoup its investment in the motor carrier service by sale to an outsider, and in this sense is different from the condition held invalid in United States v. Seatrain Lines, Inc., 329 U.S. 424 (1947), discussed in note 21 infra. 
applicable to conditions, could be struck down because they achieve results forbidden by statute. ${ }^{21}$

In Rock I sland there was no evasion of the statutory procedure; before imposing further conditions the ICC had held a hearing which probably would have satisfied the requirements of Section 212(a)..$^{22}$ However, if the Court is ready to sustain conditions evading express limitations on agency power, it would seem that it will also uphold evasion of the implied limitation that, where a statute sets up a given procedure to attain a substantive result, only that procedure may be used. ${ }^{23}$ The Tenth Circuit has already gone so far as to hold that, under a general power to attach terms and conditions, the Federal Power Commission could issue a certificate for a pipeline to last for ten years only and thus avoid the statutory requirement that no pipeline could be abandoned without a hearing before the Commission. ${ }^{24}$

21 In United States v. Seatrain Lines, Inc., 329 U.S. 424 (1947), the Court held that the ICC could not cancel a water carrier's certificate and issue a new one limiting the type of goods that could be carried. The Commission sought to justify its action as an exercise of its power under Section 309(d) of the Interstate Commerce Act to attach terms and conditions to certificates. 54 Stat. 941 (1940), 49 U.S.C.A. $\$ 909$ (d) (1951). But the Court found that, by specifying the service to be rendered under the certificate, the Commission had achieved a result impliedly prohibited by other sections of the Act. United States v. Seatrain Lines, Inc., supra, at 431 . The Court, however, also found that the Commission had contravened some language in Section 309(d) expressly limiting its power to attach terms and conditions. In the Rock Island case, the Court distinguishes Seatrain on the ground that it involved a "change in policy" on the part of the Commission, whereas in Rock Island the conditions were simply "an additional requirement" to insure that the policy expressed by the terms of the original certificate would be followed. United States v. Rock Island Co., 340 U.S. 419, 442-43 (1951). See note 20 supra.

The following cases are in accord with Seatrain in striking down conditions achieving results forbidden by statute: Central West Utility Co. v. Federal Power Commission, 247 F.2d 306 (C.A.3d, 1957); Chicago District Pipeline Co. v. Illinois Commerce Commission, 361 Ill. 296, 197 N.E. 873 (1935); cf. Standard Airlines, Inc. v. CAB, 177 F.2d 18 (App. D.C., 1949); City of Arcata v. Green, 156 Cal. 759, 106 Pac. 86 (1909). But cf. City of Topeka v. Industrial Gas Co., 135 Kan. 646, 11 P.2d 1034 (1932).

22 See Rock Island Motor Transit Co., 55 M.C.C. 567 (1946).

${ }^{23}$ In Atlantic Coast Line R. Co. v. United States, 284 U.S. 288 (1932), discussed at 398 supra, the Court, in order to allow the ICC to avoid substantive restrictions on its power under Section 15(3) to establish through routes, allowed the ICC to avoid the Section 15(3) procedure by requiring a through route as a condition to approval of a lease. However, the hearing on the lease application probably satisfied the procedural requirements of Section 15(3).

${ }^{24}$ Sun Ray Mid-Continent Oil Co. v. Federal Power Commission, 239 F.2d 97 (C.A.10th, 1956), rev'd on other grounds 353 U.S. 944 (1957). Contra: Central West Utility Co. v. Federal Power Commission, 247 F.2d 306 (C.A.3d, 1957).

The liberal attitude of the Court to conditions evading statutory restrictions seems inconsistent with cases involving unconstitutional conditions. In United States v. Chicago, Milwaukee, St. Paul \& Pac. R. Co., 282 U.S. 311 (1931), the Court held that the ICC could not, by attaching conditions to approval of a reorganization plan, impose an arbitrary regulation of matters beyond the commerce power. Other cases indicate that constitutional restrictions apply to conditions of government employment and conditions to use of the second-class mailing privilege. Wieman v. Updegraff, 344 U.S. 183 (1952); Hannegan v. Esquire, Inc., 327 U.S. 146 (1944). But cf. Massachusetts v. Mellon, 262 U.S. 447, 482-83 (1923). There seems little 
Terms and conditions might be invalidated if a procedure for regulating the same matters has been entrusted to another agency by another statute. It might seem that the case for imposing an implied limitation on a power to attach conditions would be stronger where the limiting section is in the same statute as the section granting the power. However, while there are no federal cases on point, the presence of a conflict between agencies will probably make courts more ready to strike down conditions.

While the Court seems unwilling to infer from particular sections of a statute any limitations on a general power to attach conditions, it might infer such a limitation from the "scope of the statute." In United States v. American Trucking $A s s^{\prime} n{ }^{25}$ the Court considered the extent of the ICC's power under Section 204(a) of the Interstate Commerce Act to "regulate . . . carriers by motor vehicle ... and to that end establish reasonable requirements with respect to .. qualifications and maximum hours of service of employees." ${ }^{\prime 26}$ The ICC had determined that under this section it could regulate only employees "whose activities affect the safety of operation." ${ }^{27}$ The Court upheld this limitation, in a 5-4 decision, by viewing the general language of Section 204(a) in the context of the whole Act. ${ }^{28}$ The Court referred to a supposed general practice in transportation legislation to regulate qualifications and hours of only those workers employed in matters of movement and safety. The Court also argued that the legislative history of the Act reveals no consideration of labor regulation except in connection with safety regulation. However, the rationale of the opinion seems best expressed by the language of the Commission, quoted with apparent approval by the Court: The Commission found

a clear intent of Congress to limit our jurisdiction to regulating the motor-carrier industry as a part of the transportation system of the nation. To extend that regulation to features which are not characteristic of transportation or inherent in that industry strikes us as ... unwarranted. ...29

The puzzling feature of the American Trucking decision is that the arguments used there seem inconsistent with United States v. Lowden ${ }^{30}$ and ICC v. Railway Labor Executives Ass' $n$, which uphold imposition by the ICC of labor protec-

reason why statutory restrictions should limit a power to attach conditions any less than do constitutional restrictions. At least one court has cited cases on unconstitutional conditions as authority for imposing statutory limitations on the power to attach conditions. Village of Lombard v. Illinois Bell Telephone Co., 405 Jll. 209, 90 N.E.2d 105 (1950).

25310 U.S. 534 (1940).

2849 Stat. 546 (1935), 49 U.S.C.A. \$ 304(a) (1951).

${ }^{27}$ See United States v. American Trucking Ass'n, 310 U.S. 534, 540 (1940).

28 Id., at 542-44.

29 Jurisdiction over Employees of Motor Carriers, 13 M.C.C. 481,489 (1939), quoted in

United States v. American Trucking Ass'n, 310 U.S. 534, 540-41 (1940).

${ }^{30} 308$ U.S. 225 (1939).

315 U.S. 373 (1942). 
tive conditions to approval of railway mergers and abandonments. These conditions went beyond safety regulation, with no more statutory justification than was present in the American Trucking case. Lowden and Railway Labor argue that any labor regulation which might conceivably prevent labor unrest in transportation falls within the function of the ICC to maintain an adequate national transportation system; acceptance of such an argument in American Trucking would have led to an opposite result from the one reached. While the Court in American Trucking placed heavy reliance on the administrative interpretation of the ICC, which had argued for limiting its own jurisdiction, the Railway Labor case also presented the spectacle of the ICC urging limitation of its own jurisdiction. American Trucking does not cite Lowden, decided only one year previously, and is not cited in Railway Labor, decided only two years later.

The key to these three cases might be the extensiveness of the regulation attempted. In the Lowden case, the ICC ordered compensation to be paid to a few employees affected by a merger; in American Trucking the question was whether the ICC should undertake the continuing regulation of hours and qualifications of all the carriers' employees. The Lowden kind of regulation was a temporary adjustment, to occur only when railways merged. ${ }^{32}$ The distinction between continuing and comprehensive regulation, and temporary adjustment, might be formulated in terms of a distinction between rules and conditions; in American Trucking rule-making was probably contemplated, while the Lowden and Railway Labor cases involved terms and conditions. However, such a distinction would cause agencies to promulgate their more doubtful regulatory schemes in the form of terms and conditions; if comprehensiveness and permanence of the regulation attempted is to be the test of agency jurisdiction, the formal distinction between rules and conditions will eventually have to be disregarded. ${ }^{33}$

The Administrative Code proposed by the Hoover Commission provides that [T]erms, conditions, or requirements limiting any license shall be invalid to the extent that they are found ... not to be plainly and reasonably in the public interest or not within the purposes, scope, or stated terms of the statute pursuant to which the license is issued or required. ${ }^{34}$

32 In the Railway Labor case, the extent of the labor protective conditions was left to the decision of the ICC on remand. ICC v. Railway Labor Executives Ass'n, 315 U.S. 373, 380 (1942).

${ }^{33}$ A number of state cases strike down conditions as beyond the general scope of the statute, despite the lack of any specific provision circumvented by the conditions. Village of Lombard v. Illinois Bell Telephone Co., 405 Ill. 209, 90 N.E.2d 105 (1950); Nicely v. Public Service Commission, 129 W.Va. 680, 41 S.E.2d 297 (1947); Dep't of Public Utilities v. R. O. McConnell, 198 Ark. 502, 130 S.W.2d 9 (1939); People ex rel. Iroquois Gas Corp. v. Public Service Commission, 264 N.Y. 17, 189 N.E. 764 (1934); In re Lincoln Traction Co., 103 Neb. 229, 171 N.W. 192 (1919); cf. Dakota Central Telephone Co. v. City of Huron, 165 Fed. 226 (C.C. S.D., 1908); New England Telephone \& Telegraph Co. v. City of Brockton, 332 Mass. 662, 127 N.E.2d 301 (1955).

34 Hoover Task Force Proposal for an Administrative Code, Sec. 203(b) (1956), quoted in Stason and Cooper, Cases and Other Materials on Administrative Tribunals 99 (1957). 
Aside from the excessively broad language regarding "public interest," this proposal appears to be desirable legislation. While in theory the proposed limitations should also apply to rule-making, the cases indicate necessity for reform only in regard to terms and conditions. The proposal might, however, be expanded to include agency action other than licensing. It might be argued that the proposed section would have no effect, for all the cases upholding conditions have argued that the agency stayed within the "stated terms" of the statute applicable to conditions; the issue is which terms of the statute are applicable. Moreover, the "purposes" and "scope" of a statute are matters peculiarly subject to expansive definition. However, the section could still have some effect were it taken as an expression of a legislative "mood" excessive use of the power to attach terms and conditions.

${ }^{35}$ Universal Camera Corp. v. NLRB, 340 U.S. 474 (1951). 